\title{
The Wa-Pa-Su Project Sustainability Rating System: A Simulated Case Study of Implementation and Sustainability Assessment
}

\author{
Cesar A. Poveda (Corresponding author) \\ Department of Mechanical Engineering, University of Alberta \\ 4 - 9 Mechanical Engineering Building, Edmonton, Alberta T6G 2G8, Canada \\ Tel: 1-780-619-1872 E-mail:poveda@ualberta.ca
}

\author{
Michael G. Lipsett \\ Department of Mechanical Engineering, University of Alberta \\ 5 - 8J Mechanical Engineering Building, Edmonton, Alberta T6G 2G8, Canada \\ Tel: 1-780-492-9494_Email: mlipsett@ualberta.ca
}

Received: November 25, 2013 Accepted: December 12, 2013

doi:10.5296/emsd.v3i1.4613 URL: http://dx.doi.org/10.5296/emsd.v3i1.4613

\begin{abstract}
Large-scale projects create a variety of social, economic, and environmental impacts throughout their life cycles. Assessing sustainable development becomes a measurable factor, not only for the organizations directly involved in the development, construction, and operation of projects, but also for a number of other stakeholders. In the oil sands and in heavy oil operations, assessment turns into a periodical task, since the construction and operation phases of the projects can last for a considerable period of time. The sustainability assessment tool must have the capability for the organizations and/or projects to evaluate and improve performance over time. The Wa-Pa-Su project sustainability rating system's design and characteristics meet the sustainability assessment needs of the oil sands and heavy oil operations; therefore, the development of its structure is based to support each area of operation (i.e., sub-divisions) and address the diverse impacts (i.e., areas of excellence) in each pillar of sustainability (i.e., social, economic, and environmental). Though the different sustainable development indicators (SDIs) are incorporated with the aim of measuring the sustainable development of the oil sands projects, the assessment methodology used for measuring sustainability can be implemented in a large range of projects and organizations
\end{abstract}




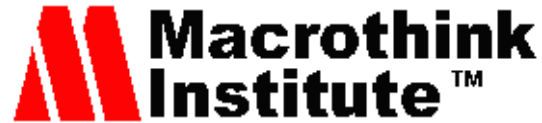

Environmental Management and Sustainable Development

ISSN 2164-7682

2014, Vol. 3, No. 1

due to its integrated approach. Since the Wa-Pa-Su project sustainability rating system is the first of its kind focusing on industrial projects with an emphasis in oil sands and heavy oil, it must be understood that a variety of SDIs have not yet been measured, and the data required for this purpose have not been collected; therefore, the objective of this paper is to highlight the flexibility and applicability of the rating system by presenting a simulated case study of implementation and sustainability assessment using an integrated approach.

Keywords: sustainability, sustainable development, sustainability assessment, quantification methods, oil sands, heavy oil, sustainable development indicators (SDIs)

\section{Introduction: Sustainability Assessment and Rating Systems}

Minimizing the detrimental effects on the natural environment due to construction practices is an existing concern (Cole, 1999; Holmes \& Hudson, 2000). Younger generations and society in general are becoming more aware of the different impacts intrinsically carried by organizations and projects in their operations and the need for finding a more sustainable path; the increase in the levels of awareness helps explain the exponential increment in the development of sustainability assessment tools. Sustainability of current operations and possible future improvements to meet goals and objectives are the main target for the development of approaches, strategies, models, appraisals, and methodologies for sustainability assessment; however, the development of efficient and reliable assessment methods and their respective tools is a challenge for both academia and the scientific community (Ness, Urbel-Piirsalu, Anderberg, \& Olsson, 2007; Mateus \& Braganca, 2011).

Sustainability is a multi-disciplinary area in permanent evolution; therefore, assessment tools evolve in parallel to meet new requirements and overcome existing and emerging limitations. Social, economic, and environmental aspects require balanced and integrated approaches for implementation and measurement. While most current sustainability assessment tools focus on one aspect of sustainability, which often refers to the environmental pillar, very few present an integral approach that considers the interlink ages and dynamics of all three pillars of sustainability (Singh, Murty, Gupta, \& Dikshit, 2012). In fact, the assessment of economic and social aspects has emerged to contribute defining the progress towards sustainable development in developing countries (Gibberd, 2005); therefore, integrated assessment systems require not only the identification of dynamics among the social, economic, and environmental parameters, but also the collection and analysis of much more detailed information.

Sustainability assessment tools gather information for decision-making; therefore, the systems can be designed targeting a specific aspect or various aspects of sustainability. Hasting and Wall (2007) group these systems in cumulative energy demand (CED) systems, which focus on energy consumption; life cycle analysis (LCA) systems, which focus on environmental aspects; and total quality assessment (TQA) systems, which evaluate ecological, economic, and social aspects. The multi-criteria systems are the most common type of TQA systems, and aim at including the three pillars of sustainability (Berardi, 2012). Multi-criteria systems compare the real performance of different parameters with predetermined baselines or thresholds. In environmental or sustainability rating systems each criterion included in the multi-criteria system has a certain number of points, and the overall organization or project 
sustainability score comes out by summing the results of the assessed criteria.

Although environmental or sustainability rating systems are widely used, the development and application of the tools have been concentrated in the building industry (Poveda \& Lipsett, 2011a). In the 1990s, the building industry not only recognized the impact of its activities, but also the need for mitigating the environmental impact of the building sector driven by public policy and market demand for environmentally-sound products and services (Haapio \& Viitaniemi, 2008). Ding (2008) groups the different tools for sustainability assessment of buildings into assessment and rating tools. Assessment tools provide a qualitative understanding of the building performance, which is used for design purposes, while rating tools determine building performance level with starts or points being awarded based on the criteria met within a specific certification process. Although each rating system and certification tool presents a specific structure, commonalities are found in categories of building design and life cycle performance: water, materials, energy, site, and indoor environment (Braganca, Mateus, \& Koukkari, 2010).

The Building Research Establishment Environmental Assessment Method (BREEAM) was the first real attempt to develop a comprehensive building performance assessment method to meet the different needs of relevant interest groups (Crawley \& Aho 1999; Ding 2008). Currently, more than 600 sustainability assessment rating systems are available and used worldwide (Building Research Establishment [BRE], 2008) with the only exceptions being Africa (except South Africa) and Latin America (except Brazil) (Berardi, 2012). If the success of environmental and sustainability rating systems is measured by the numbers of projects or square meters certified, then Bloom and Wheelock (2010) indicate that 650 million square meters obtained a sustainability certification in 2010 with projections of 1100 and 4600 million square meters for 2012 and 2020, respectively.

Environmental and sustainability rating systems target different performance aspects of the building in different stages of the life cycle. The aim of the assessment tools is to promote sustainable practices in the building industry during design, construction, operation, maintenance, disassembly or deconstruction, and disposal while integrating social, economic, and environmental needs and the concerns of the different stakeholders. Therefore, the purpose of sustainability assessment is to gather information to support decision-making during the project's life cycle (Mateus \& Braganca, 2011).

Rating systems are easy to understand, and they enable performance assessment of the building in several stages (Berardi, 2012). Currently, rating systems strongly support the design process of a building (Braganca et al., 2010), but there is a trend for covering the construction, operation, and dismantling phases with a whole-life-perspective analysis; consequently, the evolution of any rating system must continue to cover the multidimensionality of sustainability while improving the triple bottom line of buildings (Berardi, 2012).

\section{The Wa-Pa-Su Project Sustainability Rating System and its Applicability to Oil Sands Projects}

The Wa-Pa-Su project sustainability rating system is a verification process to assist in 


\section{Macrothink}

demonstrating compliance in sustainable development performance during a project's life cycle through the implementation of enhanced strategies to mitigate environmental, social, health, and economic impacts. The origins of the rating system date back to 2008 , as a $\mathrm{PhD}$ project in the Engineering Management program at the University of Alberta that was conducted as an independent research study (Poveda, 2013). The rating system proposes a framework for measuring - in a consistent manner - the sustainability of the development of oil sands and heavy oil projects. While the original intent was to target the oil sands and heavy oil projects (Poveda \& Lipsett, 2011a), the methodology for determining the rating structure and the assessment methodology to calculate the criteria weights and final sustainability scores can be used for designing rating systems with applicability across different industry contexts.

The name of the rating system addresses three facets: history, Aboriginal heritage, and sustainable development. The first non-indeigenous man to see bitumen from the largest oil deposit in Canada was Henry Kelsey, manager of the Hudson's Bay Company (HBC) at York Factory, when a Cree man named Wa-Pa-Su brought him a sample in 1719. In the Plains Cree language, wâpisiw (pronounced and commonly Anglicized as wa-pa-su) means "white swan." Finally, considering the goals and objectives of sustainable development, the acronym denotes World And People Align for Sustainability.

Figure 1 shows the logo adopted to represent the rating system. The logo's colour symbolizes the "green," sustainable path that must be the aim of developers, government, local communities, and stakeholders in general. The drop of oil and the maple leaf represent the resource and its country of origin, respectively. The maple leaf also suggests the country in which the first sustainability rating system for industrial projects with application to oil sands and heavy oil was developed. Additionally, the immersion of the maple leaf in the drop of oil is a reminder that the resource extracted is part of a larger world market for oil.

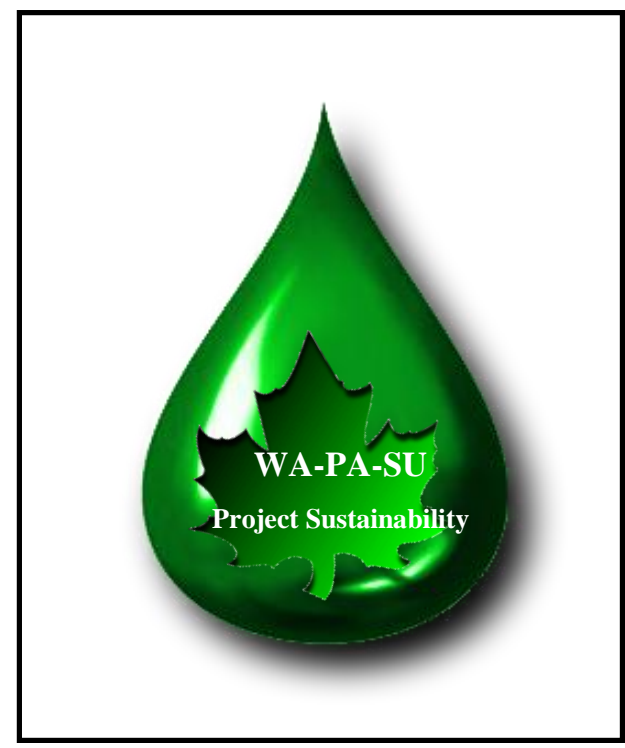

Figure 1. Wa-Pa-Su project sustainability rating system's logo 


\section{Mll Macrothink}

Environmental Management and Sustainable Development

ISSN 2164-7682

2014, Vol. 3, No. 1

The steps to determine the structure of the rating system can be summarized as follows: (1) select project or organization to be assessed, (2) identify sub-divisions (if applicable), (3) identify areas of excellence, and (4) pre-select sustainable development indicators (SDIs). Large projects or organizations may require grouping their activities in easily-identifiable areas or sub-divisions with the intent of effectively managing the different SDIs; therefore, the different activities in the oil sands and heavy oil projects are categorized in ten sub-divisions: (1) project integration; (2) provisional housing/buildings; (3) permanent housing/buildings; (4) roads; (5) oil transportation \& storage; (6) mining process; (7) in-situ process; (8) upgrading \& refining; (9) shutdown and reclamation; and (10) CO2, SOx, and the capture \& storage of other GHGs (Greenhouse gases) (Poveda \& Lipsett, 2011b). The Wa-Pa-Su project sustainability rating system takes into consideration the different resources utilized during development, stakeholder expectations, and potential environmental, economic, social, and health impacts to determine the areas of excellence. These consist of project \& environmental management excellence (PEME); site \& soil resource excellence (SSRE); water resource excellence (WRE); atmosphere \& air resource excellence (AARE); natural \& artificial lighting excellence (NALE); energy resource excellence (ERE); resources \& materials excellence (RME); innovation in design \& operations excellence (IDOE); infrastructure \& buildings excellence (IBE); and education, research, \& community excellence (ERCE).

The rating system, in its structure development methodology, proposes to analyze different sources to pre-select the SDIs to then submit the set of pre-selected SDIs to a multi-disciplinary stakeholder participatory process to weight and select the final set of SDIs. These sources can be grouped into three categories: (1) indicators agreed upon by public or governmental representatives through consensus, which include governmental regulations and committees, as well as organizations for standardization; (2) indicators identified by academics and practitioners, which include best practices in management and processes as well as academically- and scientifically-authored resources; and (3) indicators established by organizations, including local, regional, national, and international organizations and industry sector standards and programs. Finally, each criterion under the different areas of excellence uses an acronym for simplification and identification purposes; the acronym for each criterion identifies the sub-division, area of excellence, and project phase where it belongs, accompanied by a numeric identifier. For example, PEMEID \& BC06019 refers to criterion 019 that belongs to sub-division 06 (surface mining process) for the PEME area of excellence during the initial development \& business case phase (ID \& BC).

\subsection{Assessment Methodology}

The Wa-Pa-Su project sustainability rating system introduces a new assessment methodology to calculate each criterion's final sustainability score. The sustainability assessment methodology is based on an integrated approach that includes three distinctive areas of knowledge: continual performance improvement (CPI), multi-criteria decision-making analysis (MCDM), and sustainable development. The assessment methodology can be described in the following steps: (1) calculation of each criterion's initial scores and weights; (2) calculation of the performance improvement factor (PIF); and (3) calculation of each 


\section{Macrothink}

Environmental Management and Sustainable Development

ISSN 2164-7682

2014, Vol. 3, No. 1

criterion's final score, area of excellence performance index, and overall sustainability score. The rating system and its assessment methodology award the final scores and an eventual certification based on actual performance, rewarding the implementation of strategies for improvement, which is reflected in the PIF value.

The assessment methodology utilizes the same criterion initial scores (CIS) for each criterion; it is a start value which is impacted by the criterion weight factor (CWF) and the performance indicator factor (PIF). A multi-disciplinary stakeholder participatory process defines the final criteria (CFW), sub-divisions (SDW), and area of excellence (AEW) weights through multi-criteria decision-making analysis (MCDA). The PIF is defined as "a factor to determine the degree of negative or positive improvement of each specific criterion (i.e., indicators) during a specific period of time" (Poveda \& Lipsett, 2013a), and can be calculated using Formula 1 or 2 described below:

$$
P I F=\frac{P A}{P B} \quad(1) \quad P I F=\frac{P B}{P A}
$$

Where,

$$
\begin{aligned}
& \mathrm{PA}=\text { indicator performance actual value (metric) } \\
& \mathrm{PB}=\text { indicator threshold or baseline value (metric baseline) }
\end{aligned}
$$

Higher PIF values indicate performance improvement; therefore, Formula 1 is used for criteria for which an increase of value indicates improvement (e.g., percentage of re-used excavation material). On the contrary, Formula 2 is used for criteria for which a decrease in value indicates improvement (e.g., deforestation). PIFs can be categorized into three types: (1) those based on relevance factor measurement (i.e., relevance factor or subjective stakeholder valuation), (2) those based on performance improvement (i.e., the comparative assessment method), and (3) those based on level of investment (i.e., link to economic metrics). Since PIF type I is a subjective valuation, Poveda and Lipsett (2013a) propose the use of graphs in which the stakeholder valuation is linked to objective metrics (e.g., energy consumption, GHG emissions, or BBL/D [oil \& gas industry]).

Finally, the final score for each criterion is calculated using Formula 3 or 4, as described below:

$$
\mathrm{CFS}=\mathrm{CIS} \times[\mathrm{CWFx} \text { PIF }](3)
$$

Or,

$$
\text { CFS }=10000 \times[\text { SDW } \times \text { AEW } \times \text { CFW } \times \text { PIF }](4)
$$

Where, CIS $=$ criterion initial score

$\mathrm{CWF}=$ criterion weight factor 
$\mathrm{PIF}=$ criterion performance indicator factor

$10000=$ rating system total available points

SDW $=$ sub-division weight

$\mathrm{AEW}=$ area of excellence weight

$\mathrm{CFW}=$ criterion final weight

$\mathrm{CFS}=$ criterion final score

As noted, each criterion starts with the same score (CIS); however, different weights and the actual organization's or project's performance determines the final score of the criteria. Since the different weights' values range from 0 to 1 , the CIS value of 10,000 is recommended for practicability purposes, as some criteria's final scores (CFS) may be too small.

\section{The Canadian Oil Sands Projects: Surface Mining Operations}

The Canadian oil sands are located in three main deposits in the northern half of the province of Alberta: the Athabasca, Peace River, and Cold Lake. After the Venezuelan heavy oil and Saudi Arabian conventional oil deposits, the Canadian oil sands rank third in the world, with 168.7 billion barrels of proven oil reserves (Alberta Energy, 2013). Different in-situ (Latin, meaning "in place") methodologies can be utilized to potentially recover up to $80 \%$ of the oil sands, while the remaining $20 \%$ are recoverable through open-pit mining (i.e., surface mining) operations. The surface mining process involves using electric and hydraulic shovels with a capacity of up to $45 \mathrm{~m} 3$ to extract those oil sands that are within $75 \mathrm{~m}$ of the surface. The extracted material is scooped into trucks with a carrying capacity of up to 400 tons, and transported to crushers where the material (i.e., large clumps of earth) is broken down. The mixture of sand, clay or other minerals, water, and bitumen is known as oil sands, and is diluted using water and diluent (naphthenic and paraffinic), to then be transported to a plant in which the bitumen is separated from the other components (i.e., the clay or other minerals, sand, water, and chemicals). At this point, the recovered bitumen continues its course for upgrading and refining in order to become synthetic oil, while the other components are sent to the tailings ponds areas after maximizing the water recycling process.

Surface mining operations currently cover about $500 \mathrm{~km} 2$ of the 140,000 km2 of oil sands deposits resulting in a variety of social, economic, health, and environmental impacts (Poveda \& Lipsett, 2013b). While greenhouse gas emissions, land use, water use, and tailings ponds are among the most common environmental impacts from the oil sands (Canadian Association of Petroleum Producers [CAPP], 2013), different stakeholders are increasingly raising concerns regarding the non-environmental impacts resulting from the various oil sands operations; therefore, there is the need not only for developing but also implementing a tool to measure - in a consistent manner - the sustainability of the oil sands operations.

\subsection{Current Sustainable Development Performance Reporting}

Different Canadian oil sands developers and operators present the sustainability performance results of their operations in a non-compulsory report. The different metrics, indicators, and/or key performance indicators (KPI) are shown in Table 1 for a handful of the developers and operators currently exploiting the oil sands resource. The areas and key performance 
indicators included in each report varies from one company to another, and this affects any attempt to benchmark performance. Moreover, the available reports present a variety of communalities: (1) the different metrics or indicators are arbitrarily selected by the reporting organization; (2) the reporting data shows the organization's overall performance instead of the specific area (i.e., sub-division) in which the task was performed; (3) differentiation between different levels of performance cannot be made, as baselines or thresholds are not part of the reporting data; (4) there is no indication of the relevance or importance (i.e., weight) of each metric or indicator in comparison to others; and (5) the reports present the performance data for each metric or indicator but do not assign scores, leaving the results open to interpretation.

Oil sands developers and operators use metrics, indicators, and/or KPIs to measure progress towards sustainable development; however, certain areas of performance lack a similar set of reporting tools, which can be attributed to the characteristics being intrinsically subjective.

ConocoPhillips reports their performance in seven areas: air quality, greenhouse gases, land management and biodiversity, water use and quality, stakeholder engagement and aboriginal peoples, community investment, and waste (ConocoPhillips, 2013). Although ConocoPhillips presents the results using objective metrics that help facilitate the interpretation of data, there is a lack of consistency in their reporting, as some metrics' last available performance data dates back to 2009, while for others, the most up-to-date available data dates back to 2011.

Suncor reports environmental, social, and economic performance results and goals to stakeholders using objective and subjective metrics. The environmental areas of focus include water, land and biodiversity, energy efficiency and greenhouse gas emissions, air, renewable energy, and tailings. Suncor has clear environmental performance goals, with the aim to reduce fresh water consumption by $12 \%$, increase reclamation of disturbed land area by $10 \%$, improve energy efficiency by $10 \%$, and reduce air emission by $10 \%$ by the year 2015 (Suncor, 2013). With the exception of some highlighted areas of performance, Suncor's report does not include a tabulated yearly comparison of every metric included in each area; Table 1 includes only objectives metrics and indicators extracted from Suncor's Report on Sustainability 2013 (Suncor, 2013).

Canadian Natural Resources Limited (CNRL) presents the performance results in its annual Stewardship Report to Stakeholders; the last available report dates back to 2011, in which the results are grouped into the areas of safety, environment (land, water, spills, waste, air and GHG emissions, emissions intensity, and flaring and venting), and employment. Additionally, CNRL includes in its report a list of indicators as part of the Global Reporting Initiative (GRI) index; however, the report does not show the performance results (i.e., actual values), but instead sends the reader to four sources where the information can be found: the annual information form, annual report, stewardship report to stakeholders, and the management information circular (Canadian Natural, 2013).

The 2010-11 Sustainability Report is the latest document to provide information on Syncrude's performance in the areas of finance and economic contribution, stakeholder and employee engagement, community investment, health and safety, and environmental 
stewardship (Syncrude, 2013). Performance is grouped into the areas of environmental, social, and economic. The environmental section includes air quality, biodiversity, climate change, land reclamation, tailings management, water management, and waste management. The social section includes community involvement, people, labour relations, stakeholder relations (non-aboriginal), aboriginal relations, and safety \& health. Finance and operations, economic contribution, and research and development are included in the economic area of performance.

Cenovus identifies 39 corporate responsibility issues of key concern to internal and external stakeholders; the report focuses on environmental, social, and governance issues grouped as follows: economic (financial and operating), leadership and corporate governance and business practices, people (health and safety, workforce, and health and wellness), environmental performance (air, greenhouse gases [GHGs], energy, land, water, waste, energy efficiency, and R\&D), stakeholder and aboriginal engagement, and community involvement and investment (Cenovus, 2013).

Finally, Shell Canada reports performance focusing in three main areas: environment, community, and reclamation. Within those three areas, the oil sands performance report data contains information regarding safety, $\mathrm{CO} 2$, water, tailings, land and reclamation, and community (Shell Canada, 2012).

\section{Data Required and Stakeholder Involvement}

Since the rating system, in its application to oil sands, is divided into ten sub-divisions aligned with a project's life cycle, the implementation of a sustainability rating system in the oil sands projects facilitates benchmarking performance among projects (i.e., sub-divisions) with similar characteristics. Although not all of the sub-divisions are part of every oil sands project, the "Lego" methodology adopted in the structure the Wa-Pa-Su project sustainability rating system facilitates the assessment of one, several, or all of the sub-divisions included in the rating system's structure. Moreover, the application toward complex and diversified projects such as the oil sands demonstrates the flexibility and adaptability of the structure design, and integrated assessment methodology used in the rating system.

The project or organization sustainability assessment plan requires the development and implementation of data collection, analysis, and reporting processes. Once the implementation of the rating system has been determined, the status of the current data collection must be determined. Currently, most oil sands developers and operators report their performance through different metrics, indicators, and/or KPIs for sustainability. Through comparing current data collection practices with the Wa-Pa-Su project sustainability rating system requirements, users can evaluate the additional needs and standards for evaluating sustainability performance and assessing the organization or project's sustainability score. 
Table 1. Metrics, indicators and/or KPIs for sustainability performance reporting by oil sands developers and operators

\begin{tabular}{|c|c|c|}
\hline \multicolumn{3}{|c|}{ CONOCOPHILLIPS } \\
\hline Air Emissions & Greenhouse Gases & Land Management and Biodiversity \\
\hline Flared gas volumes $\left(\mathrm{E}^{3} \mathrm{~m}^{3}\right)$ & \multirow{6}{*}{$\begin{array}{l}\text { Direct carbon dioxide }\left(\mathrm{CO}_{2}\right) \text { emitted }(\mathrm{kT}) \\
\text { Directed methane emitted expressed as } \mathrm{CO}_{2} \mathrm{e}(\mathrm{kT}) \\
\text { Direct nitrous oxide emitted expressed as } \mathrm{CO}_{2} \mathrm{e}(\mathrm{kT}) \\
\text { Direct carbon dioxide equivalent emissions }(\mathrm{kT}) \\
\text { Indirect carbon dioxide equivalent emissions }(\mathrm{kT}) \\
\text { Direct carbon dioxide }\left(\mathrm{CO}_{2} \mathrm{e}\right) \text { intensity }\left(\mathrm{kT} / \mathrm{E}^{3} \mathrm{~m}^{3} \mathrm{OE}\right) \\
\end{array}$} & \multirow{7}{*}{$\begin{array}{l}\text { New linear features requiring new cut }(\mathrm{km}) \\
\text { New footprint (delineation wells) (ha) } \\
\text { Current disturbed land for Surmount Phase I and } \\
\text { Pilot Plant (ha) } \\
\text { Current disturbed land for Phase } 22009 \text { only (ha) } \\
\text { Research support for species of management } \\
\text { concern (\$) }\end{array}$} \\
\hline Vented gas volumes $\left(\mathrm{E}^{3} \mathrm{~m}^{3}\right)$ & & \\
\hline Benzene emitted from glycol dehydrators (kT) & & \\
\hline Oxides of nitrogen (NOx) emitted (kT) & & \\
\hline Sulphur oxides (Sox) emitted (kT) & & \\
\hline Particulate matter (PM) emitted (kT) & & \\
\hline Volatile Organic Compounds (VOCs) emitted & \multirow{4}{*}{$\begin{array}{l}\text { Leaks and Spills } \\
\text { Number of produced water spills to land }(>1 \mathrm{bbl}) \\
\text { Total volume produced water spilled to land }(>1 \mathrm{bbl}) \\
\left(\mathrm{m}^{3}\right) \\
\text { Total volume of produced recovered }\left(\mathrm{m}^{3}\right)\end{array}$} & \\
\hline $\begin{array}{l}\text { (excludes methane and benzene) (kT) } \\
\text { Natural gas fuel usage }\left(10^{3} \mathrm{~m}^{3}\right)\end{array}$ & & \multirow{2}{*}{$\begin{array}{l}\text { Valued Ecosystem Components (VECs) that are } \\
\text { species of management concern }(\%) \\
\text { Low impact }(\mathrm{km})\end{array}$} \\
\hline Water Use (Pilot and Phase I) & & \\
\hline Non-saline groundwater used $\left(\mathrm{m}^{3}\right)$ & & \multirow{6}{*}{$\begin{array}{l}\text { Report size of seismic lines (m) } \\
\text { Low seismic impact overall (ha) } \\
\text { Reclamation certificate received (RCR) } \\
\text { Abandoned and un-reclaimed wells } \\
\text { Number of hectares reforested } \\
\text { Total number of reclaimed and abandoned wells in } \\
\text { Alberta }\end{array}$} \\
\hline Saline groundwater used $\left(\mathrm{m}^{3}\right)$ & \multirow{3}{*}{$\begin{array}{l}\text { Portion of produced water recovered }(\%) \\
\text { Volume of produced water spilled intensity } \\
\left(\mathrm{m}^{3} / 10^{3} \mathrm{~m}^{3} \mathrm{OE}\right)\end{array}$} & \\
\hline Produced water used $\left(\mathrm{m}^{3}\right)$ & & \\
\hline Steam injected $\left(\mathrm{m}^{3}\right)$ & & \\
\hline Produced water disposed $\left(\mathrm{m}^{3}\right)$ & \multirow{6}{*}{$\begin{array}{l}\text { Hydrocarbon spills } \\
\text { Volume hydrocarbon spilled }\left(\mathrm{m}^{3}\right) \\
\text { Volume hydrocarbon recovered }\left(\mathrm{m}^{3}\right) \\
\text { Portion of hydrocarbon recovered }(\%) \\
\text { Volume of hydrocarbon spilled intensity }\left(\mathrm{m}^{3} / 10^{3} \mathrm{~m}^{3} \mathrm{OE}\right) \\
\text { Number of pipeline incidents } \\
\text { Number of pipeline leaks } \\
\text { Leaks per } 1,000 \mathrm{~km} \text { of pipeline }\end{array}$} & \\
\hline $\begin{array}{l}\text { Water used per barrel of oil produced (bbls } \\
\text { water/BOE) }\end{array}$ & & \\
\hline Water used for drilling, completions \& & & Regulatory Compliance \\
\hline abandonment $\left(\mathrm{m}^{3}\right)$ & & $\begin{array}{l}\text { Number of times ConocoPhillips Canada was } \\
\text { placed on the ERCB heightened level (persistence) }\end{array}$ \\
\hline Water Use (Pilot and Phase 1) & & \multirow{5}{*}{$\begin{array}{l}\text { Community Investment } \\
\text { Community investment expenditure (\$) } \\
\text { Community benefits expenditure (\$) } \\
\text { Community investment expenditure - Join Venture } \\
(\$) \\
\text { Local workers that participated in safety training } \\
\text { Local contracts } \\
\text { Community investment to nearby Aboriginal } \\
\text { communities (\$) }\end{array}$} \\
\hline Groundwater used (fresh) $\left(\mathrm{m}^{3}\right)$ & & \\
\hline Ground used (fresh) $\left(\mathrm{m}^{3}\right)$ & $\begin{array}{l}\text { Stakeholder Engagement } \\
\end{array}$ & \\
\hline $\begin{array}{l}\text { Produced water disposed }\left(\mathrm{m}^{3}\right) \\
\text { Steam injected }\left(\mathrm{m}^{3}\right) \\
\text { Water used per barrel of oil produced (bbls } \\
\text { water/BOE) }\end{array}$ & \multirow[t]{4}{*}{$\begin{array}{l}\text { Staff/consultants devoted to stakeholder engagement } \\
\text { Groups/initiatives in which the organization } \\
\text { collaborates with other companies or take a leading } \\
\text { roles }\end{array}$} & \\
\hline $\begin{array}{l}\text { Water used for drilling completions \& } \\
\text { abandonment }\left(\mathrm{m}^{3}\right)\end{array}$ & & \\
\hline Waste & & \multirow[t]{2}{*}{ Training and capacity building programs $(\$)$} \\
\hline $\begin{array}{l}\text { Hazardous waste disposed (tonnes) } \\
\text { Non-hazardous waste disposed (tonnes) } \\
\text { Waste recycled (tonnes) }\end{array}$ & & \\
\hline \multicolumn{3}{|c|}{ SUNCOR } \\
\hline Environmental & Social & Economic \\
\hline $\begin{array}{l}\text { Air emissions (tonnes/year) } \\
\mathrm{M}^{3} \text { of river water and groundwater to produce one } \\
\mathrm{m} 3 \text { of oil (mining) } \\
\text { Water withdrawal and consumption }\left(\mathrm{m}^{3}\right) \\
\text { Land use at oil sands (cumulative hectares) } \\
\text { Installed wind capacity (megawatts) } \\
\text { Hectares disturbed by mining operations } \\
\text { Hectares reclaimed } \\
\text { Number of trees planted on oil sands site } \\
\text { GHG emissions (tonnes } \mathrm{CO}_{2} \text { equivalents } \mathrm{CO}_{2} \mathrm{e} \text { ) } \\
\text { GHG emissions intensity (tonnes } \mathrm{CO}_{2} \mathrm{e} / \mathrm{m}^{3} \mathrm{OE} \text { ) }\end{array}$ & $\begin{array}{l}\text { Lost time injury frequency (injuries per } 200,000 \text { hours } \\
\text { worked) } \\
\text { Support for excellence in indigenous education (\$) } \\
\text { Number of charitable \& non-profit organizations } \\
\text { supported by employees } \\
\text { Spent on goods and services from Aboriginal business } \\
\text { (\$) }\end{array}$ & $\begin{array}{l}\text { Net production (boe/day) } \\
\text { Net earnings (\$) } \\
\text { Cash flow from operations }(\$) \\
\text { Royalties paid by Suncor }(\$) \\
\text { Suncor paid income taxes }(\$) \\
\text { Capital spending }(\$) \\
\text { Suncor spent on good and services }(\$)\end{array}$ \\
\hline \multicolumn{3}{|c|}{ CNRL } \\
\hline Safety & Environment & Employment \\
\hline $\begin{array}{l}\text { Recordable injury frequency (employees and } \\
\text { contractors) (per 200,000 hours worked) } \\
\text { Fatalities (employees) } \\
\text { Fatalities (contractors) }\end{array}$ & 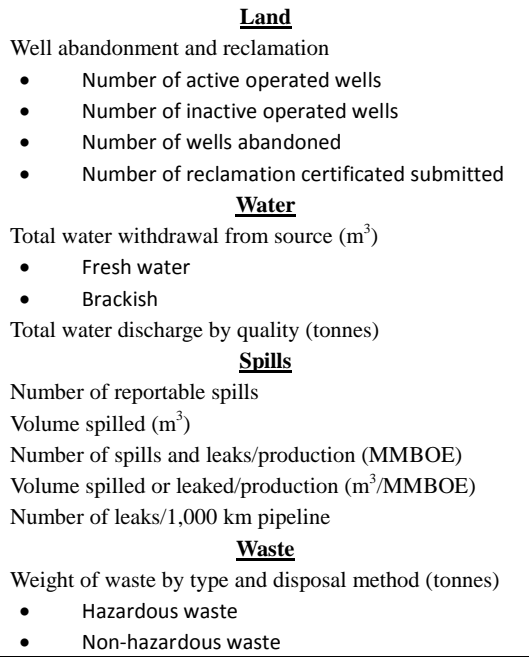 & $\begin{array}{l}\text { Distribution of Canadian Natural Employees } \\
\text { - } \quad \text { Numbers of employees } \\
\text { - } \quad \text { Exposure hours (millions) }\end{array}$ \\
\hline
\end{tabular}




\begin{tabular}{|c|c|c|}
\hline & 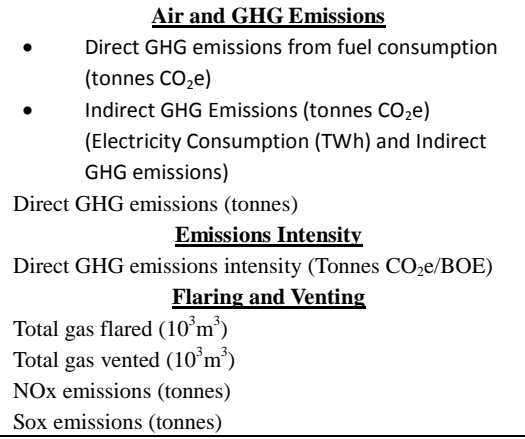 & \\
\hline \multicolumn{3}{|c|}{$\begin{array}{l}\text { Note: CNRL includes a series of indicators as part of the Global Reporting Initiative (GRI) index; however, performance values are not indicated in the Stewardship } \\
\text { Report to Stakeholders. }\end{array}$} \\
\hline \multicolumn{3}{|c|}{ SYNCRUDE } \\
\hline \multirow{8}{*}{ 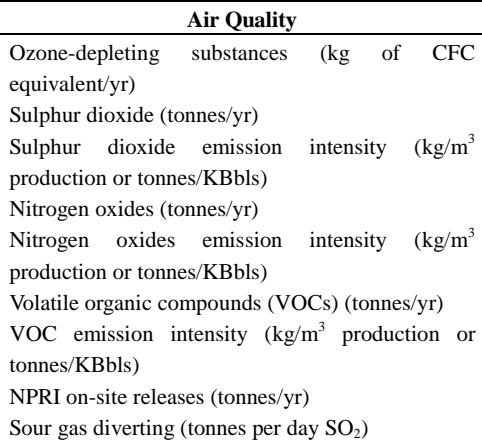 } & Biodiversity & \multirow{4}{*}{$\begin{array}{l}\text { Land Reclamation } \\
\text { Total land disturbed (cumulative hectares) } \\
\text { Soils placed-land available for revegetation } \\
\text { (hectares) } \\
\text { Temporary reclamation (hectares) } \\
\text { Permanent land reclaimed (hectares per year) } \\
\text { Permanent land reclaimed (cumulative hectares) } \\
\text { Tree and shrub seeding planted (annual) }\end{array}$} \\
\hline & No metric, indicator or KPI reported & \\
\hline & \multirow{8}{*}{\begin{tabular}{l}
\multicolumn{1}{c}{ Climate Change } \\
\multicolumn{1}{c}{ Energy Conservation } \\
Total energy consumption (BTUs) \\
Energy intensity (BTUs per barrel) \\
Energy intensity improvement ( $\%$ as compared to year \\
prior) \\
Energy return ration (BTUs of SCO product BTUs of \\
energy consumed) \\
$\quad$ Greenhouse Gas Emissions \\
GHGs-millions of tonnes (as per Environment Canada \\
quantification guidelines) \\
GHGs-millions of tonnes (as per Specified Gas \\
Emitters Regulation) \\
GHGs-tonnes $\mathrm{CO}_{2}$ e per barrel produced
\end{tabular}} & \\
\hline & & \\
\hline & & Tailings Management \\
\hline & & No metric, indicator or KPI reported \\
\hline & & \multirow{3}{*}{$\begin{array}{l}\text { Water Management } \\
\text { Imported from Athabasca River }\left(\mathrm{m}^{3}\right) \\
\text { Imported from Athabasca River }\left(\mathrm{m}^{3} / \mathrm{m}^{3} \text { production) }\right. \\
\text { Water returned to the Athabasca River-treated } \\
\text { sanitary }\left(\mathrm{m}^{3}\right) \\
\text { Water returned to the Athabasca River-other (Aurora } \\
\text { diversion) }\left(\mathrm{m}^{3}\right) \\
\text { Process water recycled }\left(\mathrm{m}^{3} \text { and } \% \text { of total water }\right. \\
\text { used) } \\
\text { Water discharge quality exceedances (treated } \\
\text { sanitary) (\# of incidents) } \\
\text { Water discharge quality exceedances (industrial } \\
\text { process) (\# of incidents) } \\
\text { Reportable spills to natural water bodies }\left(\mathrm{m}^{3}\right) \\
\end{array}$} \\
\hline & & \\
\hline \multirow{7}{*}{$\begin{array}{l}\text { Waste Management } \\
\text { Major waste recycled or reused-solid (tonnes) } \\
\text { Minor waste recycled or reused-solid (tonnes) } \\
\text { Major waste recycled or reused-liquid }\left(\mathrm{m}^{3}\right) \\
\text { Waste-solid hazardous or potential hazardous } \\
\text { material sent for off-site treatment or destruction } \\
\left(\mathrm{m}^{3}\right) \\
\text { Waste-liquid hazardous or potential hazardous } \\
\text { material sent for off-site treatment or destruction } \\
\left(\mathrm{m}^{3}\right)\end{array}$} & & \\
\hline & & \multirow{6}{*}{$\begin{array}{l}\text { Water returned to the Athabasca River-other (Aurora } \\
\text { diversion) }\left(\mathrm{m}^{3}\right) \\
\text { Process water recycled }\left(\mathrm{m}^{3} \text { and } \% \text { of total water }\right. \\
\text { used) } \\
\text { Water discharge quality exceedances (treated } \\
\text { sanitary) (\# of incidents) } \\
\text { Water discharge quality exceedances (industrial } \\
\text { process) (\# of incidents) } \\
\text { Reportable spills to natural water bodies }\left(\mathrm{m}^{3}\right)\end{array}$} \\
\hline & Community Involvement & \\
\hline & Corporate giving (\$ millions) & \\
\hline & People & \\
\hline & See online report for details. & \\
\hline & $\begin{array}{l}\text { Labour Relations, Stakeholder } \\
\text { Aboriginal, Aboriginal Relations }\end{array}$ & \\
\hline Waste disposal-onsite industrial, non-hazardous & & \multirow{6}{*}{\begin{tabular}{l}
\multicolumn{1}{c}{ Finance and Operations } \\
Total crude oil production (various units) \\
Realized SCO selling price \$ per barrel) \\
Total operating costs (various units) \\
Capital expenditures (\$) \\
Revenues (\$) \\
Retained earning \\
Bitumen produced (barrels) \\
Bitumen recovery (\%) \\
Upgrading yield (\%) \\
Environmental fines (\$) \\
Environmental protection orders (\#)
\end{tabular}} \\
\hline $\begin{array}{l}\text { (tonnes) } \\
\text { Waste disposal-on-site sanitary non-hazardous } \\
\text { (tonnes) } \\
\text { Waste disposal-off-site sanitary non-hazardous } \\
\text { (tonnes) }\end{array}$ & for activities and investments. & \\
\hline Health and Safety & Economic Contribution & \\
\hline See online report for company's statistics & Royalties, payroll \& municipal taxes (\$) & \\
\hline Research and Investment & Purchased energy (\$) & \\
\hline $\begin{array}{l}\text { No metric, indicator or KPI reported. See online } \\
\text { report for activities and investments. }\end{array}$ & $\begin{array}{l}\text { Employees (net) }(\$) \\
\text { Materials and supplies }(\$) \\
\text { Contracted services }(\$) \\
\text { Other expenditures }(\$)\end{array}$ & \\
\hline \multicolumn{3}{|c|}{ CENOVUS } \\
\hline \multirow{8}{*}{$\begin{array}{l}\quad \text { Financial } \\
\text { Net land position (hectares) } \\
\text { Common shares outstanding (\$) } \\
\text { Market capitalization (\$) } \\
\text { Gross sales (\$) } \\
\text { Cash flow (\$) } \\
\text { Annual capital investment (\$) } \\
\text { Operating expenses (\$) } \\
\text { Dividends per common share } \\
\text { Dividend yield (\%) } \\
\text { Current taxes (\$) } \\
\text { Royalties (\$) } \\
\text { Total assets (\$) } \\
\text { Debt to capitalization ratio }(\%)\end{array}$} & Operating & Health and Safety \\
\hline & \multirow{5}{*}{$\begin{array}{l}\text { Net production, before royalties }- \text { oil sands (Mbbls/d) } \\
\text { Net production, before royalties - other oil and NGLs } \\
(\mathrm{Mbbls} / \mathrm{d}) \\
\text { Net production, before royalties }- \text { natural gas } \\
(\mathrm{MMCF} / \mathrm{d}) \\
\text { Total proved reserves (MMBOE) } \\
\text { Bitumen proved reserves (MMbbls) } \\
\text { Gross production, before royalties (MBOE/d) } \\
\text { Gross production, before royalties (Mbbls/d) - oil sands }\end{array}$} & $\begin{array}{l}\text { Total recordable injury frequency (employees and } \\
\text { contractors and separately) } \\
\text { Lost time injury frequency (employees and } \\
\text { contractors and separately) } \\
\text { Fatalities (employees and contractors) }\end{array}$ \\
\hline & & $\begin{array}{l}\text { Leadership and Corporate Governance and } \\
\text { Business }\end{array}$ \\
\hline & & \multirow{5}{*}{$\begin{array}{l}\text { Business conduct investigations } \\
\text { Total incidents of violations involving rights of } \\
\text { indigenous people } \\
\text { Monetary value of significant fines and total } \\
\text { non-monetary sanctions for non-compliance with } \\
\text { laws and regulations (\$) } \\
\text { Integrity helpline intakes } \\
\text { Political donations (\$) }\end{array}$} \\
\hline & & \\
\hline & & \\
\hline & $\begin{array}{l}\mathrm{SO}_{2} \text { emissions (tonnes) } \\
\text { NOx emissions (tonnes) } \\
\text { Total gas flared }\left(\mathrm{m}^{3}\right) \\
\text { Total gas vented }\left(\mathrm{m}^{3}\right) \\
\end{array}$ & \\
\hline & & \\
\hline Health and Wellness & \multirow{2}{*}{$\begin{array}{l}\text { Direct GHG emissions (tonnes CO2E) } \\
\text { Direct GHG emissions -oil sands (tonnes CO2E) } \\
\text { Indirect GHG emissions (tonnes CO2E) }\end{array}$} & Energy \\
\hline $\begin{array}{l}\text { Field employee health assessments } \\
\text { Global Corporate Challenge (GCC)-Team fitness }\end{array}$ & & $\begin{array}{l}\text { Energy use (GJ) } \\
\text { Energy use (GJ) - oil sands }\end{array}$ \\
\hline
\end{tabular}




\section{Macrothink}

Environmental Management and Sustainable Development

ISSN 2164-7682

2014, Vol. 3, No. 1

\begin{tabular}{|c|c|c|}
\hline \multirow{4}{*}{$\begin{array}{l}\text { participation rate } \\
\text { Workstation Ergonomics Program (\% of } \\
\text { discomfort improvement post assessment) } \\
\text { Short Term Disability ( } \% \text { of employees returning } \\
\text { to work) }\end{array}$} & \multirow{7}{*}{$\begin{array}{l}\text { Indirect GHG emissions - oil sands (tonnes } \mathrm{CO} 2 \mathrm{E} \text { ) } \\
\text { Direct GHG emissions intensity (tonnes } \mathrm{CO} 2 \mathrm{E} \text { ) } \\
\text { Direct GHG emissions intensity -oil sands (tonnes } \\
\mathrm{CO} 2 \mathrm{E} \text { ) } \\
\text { Bitumen production GHG emissions intensity (\% } \\
\text { decline from 2004) } \\
\text { Cumulative mass } \mathrm{CO}_{2} \text { sequestred }\left(\mathrm{kT} \mathrm{CO}_{2}\right) \\
\text { Net mass of } \mathrm{CO}_{2} \text { stored annually(absolute, } \mathrm{kT} \mathrm{CO}_{2} \text { ) }\end{array}$} & \multirow{2}{*}{$\begin{array}{l}\text { Energy intensity }(\mathrm{GJ} / \mathrm{m} 3 \mathrm{OE}) \\
\text { Energy intensity-oil sands }(\mathrm{GJ} / \mathrm{m} 3 \mathrm{OE})\end{array}$} \\
\hline & & \\
\hline & & \multirow{7}{*}{$\begin{array}{l}\text { Land } \\
\text { Total area under reclamation (hectares) } \\
\text { Well site reclamation certificates received } \\
\text { Total wells undergoing active reclamation } \\
\text { Total reclaimed land (hectares) } \\
\text { Reportable spills (oil sands and pipelines) } \\
\text { Estimated reportable volume spilled (bbls) (oil } \\
\text { sands and pipelines) }\end{array}$} \\
\hline & & \\
\hline $\begin{array}{l}\text { Workforce } \\
\end{array}$ & & \\
\hline Total workforce (employees and contractors) & & \\
\hline Voluntary employee turnover $(\%)$ & & \\
\hline Gender breakdown of employees & Energy Efficiency and R \& D & \\
\hline Age (employees) & \multirow{10}{*}{$\begin{array}{l}\text { Cenovus Environmental Opportunity } \\
\text { Flanned spend (\$) } \\
\text { Cenovus Environmental Opportunity } \\
\text { Planned spend (\$) } \\
\text { Energy efficiency fund planned spend (\$) } \\
\text { Energy efficiency fund actual spend (\$) } \\
\text { Employee Energy Efficiency Rebate Program } \\
\text { participation (rebates issued) } \\
\text { Employee Energy Efficiency Rebate Program } \\
\text { participation (employees) } \\
\text { Employees Energy Efficiency Rebate Program - Eco } \\
\text { Kits issued } \\
\text { R\&D capital spend (\$) } \\
\text { Steam to oil ratio (Foster Creek) } \\
\text { Steam to oil ratio 9Christina Lake) } \\
\text { Industry average steam to oil ratio }\end{array}$} & \\
\hline Average age (employees) & & $\begin{array}{l}\text { Waste } \\
\end{array}$ \\
\hline Generational profile & & Hazardous (tonnes) \\
\hline Location of employees & & Non-Hazardous (tonnes) \\
\hline Employees with completed development plans (\%) & & Total waste (tonnes) \\
\hline Development sessions attended by supervisors (\%) & & Community Involvement and Investment \\
\hline $\begin{array}{l}\text { Females in management positions ( } \% \text { at VP level } \\
\text { and above) }\end{array}$ & & $\begin{array}{l}\text { Community funding (\$) } \\
\text { Community funding-Organizations supported (\#) }\end{array}$ \\
\hline Scholarships provided to dependents of employees & & LBG corporate giving in Canada \\
\hline Stakeholder and Aboriginal Engagement & & \\
\hline $\begin{array}{l}\text { Aboriginal business spending } \\
\text { Percent of total company spend }\end{array}$ & & \\
\hline \multicolumn{3}{|c|}{ SHELL } \\
\hline Safety & $\mathrm{CO}_{2}$ & \\
\hline $\begin{array}{l}\text { Exposure hours } \\
\text { Total recordable cases } \\
\text { Total recordable case frequency } \\
\text { Lost time injuries } \\
\text { Lost time injury frequency }\end{array}$ & \multirow{7}{*}{ 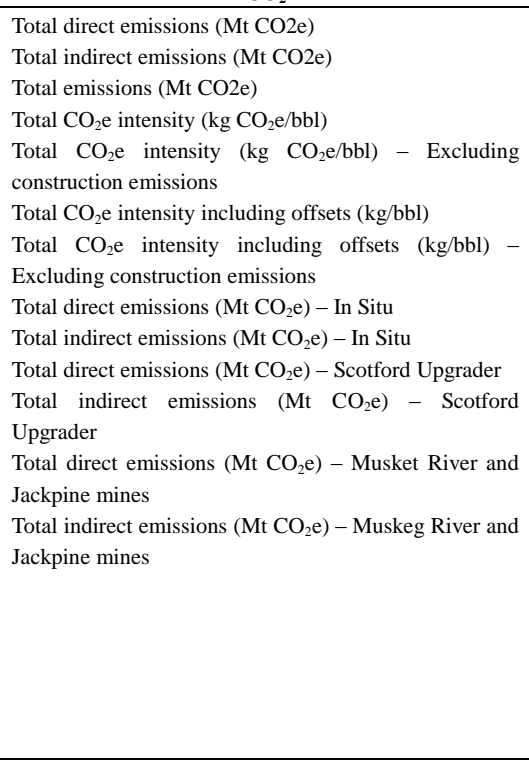 } & \multirow{7}{*}{$\begin{array}{l}\text { Scotford Upgrader } \\
\text { Total water use }\left(\mathrm{m}^{3}\right) \\
\text { Net fresh water consumption }\left(\mathrm{m}^{3}\right) \\
\text { Total effluent treated and returned to the river }\left(\mathrm{m}^{3}\right) \\
\% \text { net fresh water consumption } \\
\% \text { total effluent treated and returned to the river } \\
\text { Fresh water intensity (bbl water consumed/bbl } \\
\text { MRM and JPM bitumen) } \\
\text { Musket River Mine and Jackpine Mine } \\
\text { Total water use }\left(\mathrm{m}^{3}\right) \\
\text { Mine recycle water use }\left(\mathrm{m}^{3}\right) \\
\text { Net Athabasca River freshwater consumption }\left(\mathrm{m}^{3}\right) \\
\text { Net freshwater from other sources consumption - } \\
\left.\text { surface runoff and ground ( } \mathrm{m}^{3}\right) \\
\% \text { recycled pond water } \\
\% \text { freshwater (Athabasca River) } \\
\text { \%freshwater from other sources (surface runoff and } \\
\text { ground) } \\
\text { Freshwater intensity - Athabasca River (bbl } \\
\text { freshwater/bbl bitumen) } \\
\text { In-Situ } \\
\text { Total freshwater consumption ( } \mathrm{m}^{3} \text { ) } \\
\text { Fresh water intensity (bbl water consumed/bbl in } \\
\text { situ bitumen) }\end{array}$} \\
\hline Tailings & & \\
\hline $\begin{array}{l}\text { Total volume of liquid discharged to external } \\
\text { tailings facility \& in-pit }\left(\mathrm{m}^{3}\right)\end{array}$ & & \\
\hline Land and Reclamation & & \\
\hline $\begin{array}{l}\text { Total active footprint }- \text { mine }+ \text { plant size (ha) } \\
\text { Permanent reclamation (ha) } \\
\text { Temporary reclamation (ha) }\end{array}$ & & \\
\hline Community & & \\
\hline $\begin{array}{l}\text { Social investment spend }(\$) \\
\text { Aboriginal spend }(\$)\end{array}$ & & \\
\hline
\end{tabular}

${ }^{*}$ Metric used only in Phase 1

Effective stakeholder engagement and consensus-building increases the chances for the success of the assessment process while favouring the acceptability of the results. The creation of a multi-disciplinary stakeholder committee (MDSC) assists in the development and implementation of the rating system on several fronts. At this stage, the MDSC has already collaborated with oil sands developers and operators to determine which SDIs and metrics are to be used in the assessment of the project's and/or organization's sustainability. The MDSC comprises individuals who are directly and indirectly impacted by the oil sands operations; hence, members of the MDSC represent organizations or individuals who are affected by or affect the project's operations in one way or another. Moreover, decisions in different phases of the project's life cycle or sub-divisions may require the presence of specific members of the MDSC; therefore, stakeholder management policies within the 
organization or project determine the participation of each MDSC member as required.

The assessment methodology also requires the input of the MDSC members in the weighting process. The Wa-Pa-Su projects sustainability rating system bases the score calculation for each criterion on relevance (i.e., importance) and performance. While metrics and performance are independently designed and calculated for each criterion, the relevance is calculated through comparisons among different criteria, sub-divisions, and/or areas of excellence. Each activity in the oil sands operations represents a different degree of impact; hence, the MDSC must indicate the weight of criteria depending on the area of excellence and sub-division to which each criterion belongs. Similarly, areas of excellence and sub-divisions are to be weighted. Dividing the project or organization into sub-divisions does not imply equality in relevance (i.e., weights) among them; for example, the degree of impact of surface mining operations in the oil sands is expected to be higher than those carried in the sub-division relating to roads Additionally, the design of areas of excellence is based on the different resources involved in the project's and organization's operations, areas of concern for internal and external stakeholders, and sustainability fundamentals, the latter indicating the inclusion and balance of social, environmental, and economic parameters. Therefore, the MDSC must indicate through a weighting process the level of relevance of each area of excellence.

Finally, input from the MDSC is required to determine the performance improvement factor (PIF) for those criteria having a PIF type I. Criteria having a PIF type I can be found in any area of excellence and sub-division. Criteria with PIF type I are those calculated through stakeholder valuation, which implies a high degree of subjectivity. The MDSC must determine the relevance factor $(\mathrm{RF})$ for each criterion on a 9-point scale presented in numeric and linguistic terms; the results are compared with objective measures to determine each criterion's PIF (Poveda \& Lipsett, 2013a). Criteria having a PIF type II or III, the PIF is calculated using objectives measures. While criteria having a PIF type II use Comparative Assessment Methods (CAM), criteria having a PIF type III are linked to economic metrics to determined performance (Poveda \& Lipsett, 2013a).

\section{Assessment of Sustainability Using The Wa-Pa-Su Project Sustainability Rating System}

The surface mining process is one of the major projects undertaken in the Canadian oil sands operations; hence, a set of criteria have been selected to demonstrate how the assessment methodology utilized in the $\mathrm{Wa}-\mathrm{Pa}-\mathrm{Su}$ project sustainability rating system is implemented in practice.

After the criteria selection process, each criterion receives a code. The MDSC weights the sub-divisions, areas of excellence, and criteria through the MCDM process. The sum of the weights must equal one within each group of assessment. Tables 1, 2, and 3 show the different weights required in the assessment process, while Figure 2 shows the summary of calculation for assessing the sustainability of Project A. To demonstrate the applicability of the assessment methodology, two sets of data have been selected, and three possible scenarios are discussed: actual performance assessment, potential minimum performance, and potential 
maximum performance. Additionally, criteria having a PIF type I, II, or III are included in the simulated case study to show the application of each calculation methodology.

The first step consists of measuring the performance actual (Pactual) and setting the performance baseline (Pbaseline). Criterion PEMEP\&D06015 (Development of Environmental Management Systems) is in the group of criteria having a PIF type I. The performance of these groups of criteria is measured in a subjective manner; therefore, the PIF calculation is proposed through linking the relevance category to which the criteria belongs with the objectives measures. In this case, the relevance category for the criteria with PIF type I is linked to the organization's or project's oil production as shown in Graph 1. Criterion PEMEP\&D06015's assessment indicates a relevance category of low-high; with the organization's or project's oil production higher than $50000 \mathrm{BBL} / \mathrm{D}$, the PIF equals 1.33 . The value used to represent oil production is the average for the immediate previous year at the time of the performance assessment. Similarly, the PIF type I for other criteria are calculated. The MDSC through consensus indicates the relevance category of the set of criteria having a PIF type I. The relevance category can be linked to various objective measures (Poveda \& Lipsett, 2013a); therefore, the lowest of the different PIF values is to be selected.

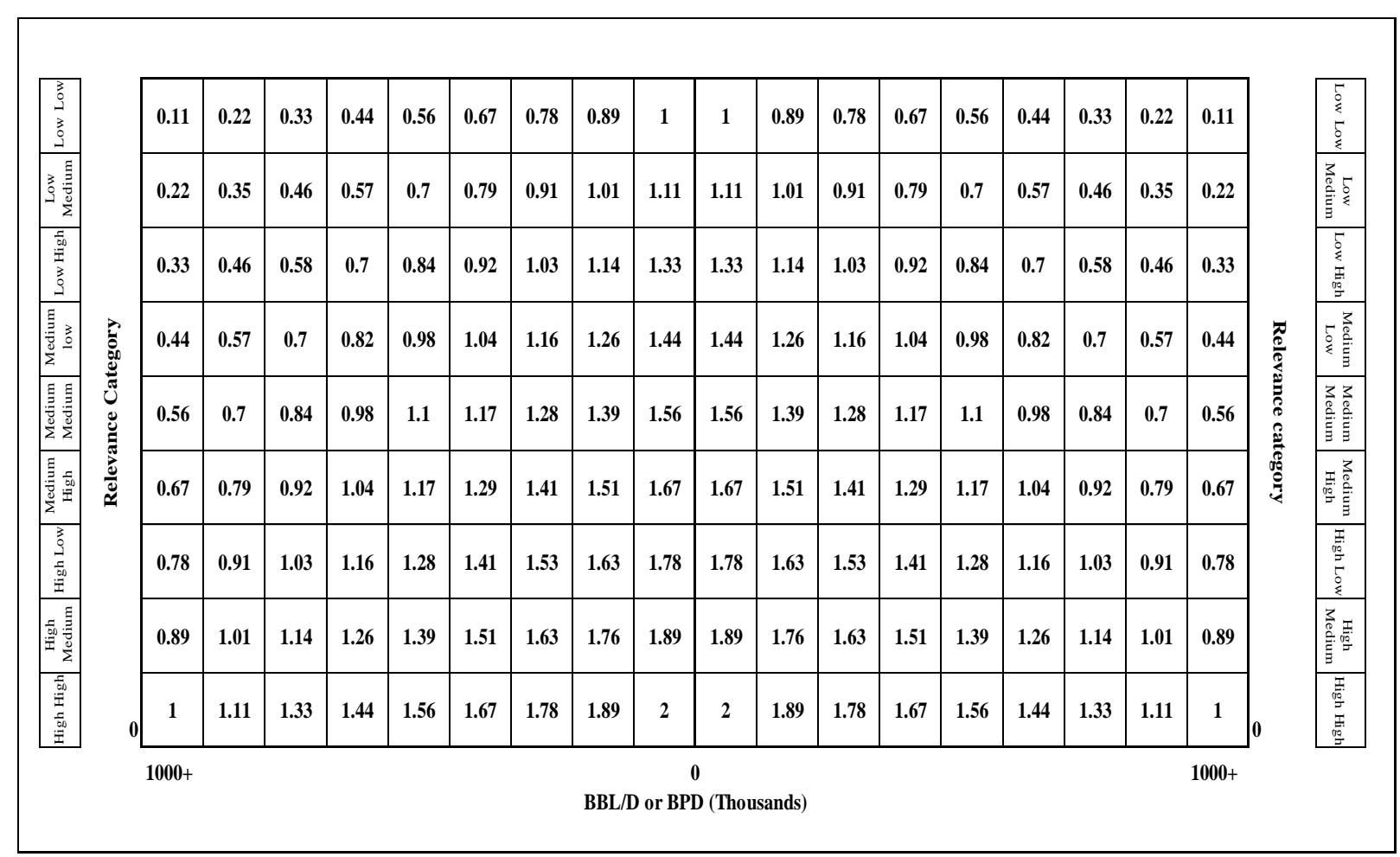

Graph 2. Relevance Factor Relations 2

Criterion SSREO06025 (Percentage of Re-used Excavation Material) belongs to the group of criteria having a PIF type II. The performance of this set of criteria is measured based on comparative assessment methods; therefore, a baseline or threshold is set to compare actual performance with pre-established guidelines. Criteria with baselines or thresholds based on 


\section{Macrothink}

Environmental Management and Sustainable Development

ISSN 2164-7682 2014, Vol. 3, No. 1

regulatory requirements are found in this group. Formula 1 is used to calculate the PIF for each criterion; hence, the PIF for criterion SSREO06025 is:

$$
\mathrm{PIF}=\frac{0.92}{0.90}=1.02
$$

Table 2. Sub-division's weights projects A and B.

\begin{tabular}{|l|c|c|}
\cline { 2 - 3 } \multicolumn{1}{c|}{} & \multicolumn{2}{c|}{ Weights } \\
\hline Sub-Division & $\begin{array}{c}\text { Project } \\
\text { A }\end{array}$ & $\begin{array}{c}\text { Project } \\
\text { B }\end{array}$ \\
\hline Project integration & 0.08 & 0.06 \\
\hline Provision housing/buildings & 0.05 & 0.04 \\
\hline Permanent housing/buildings & 0.07 & 0.06 \\
\hline Roads & 0.10 & 0.11 \\
\hline Oil transportation \& Storage & 0.12 & 0.09 \\
\hline Mining Process & 0.16 & 0.21 \\
\hline In-situ Process & 0.10 & 0.12 \\
\hline Upgrading \& refining & 0.13 & 0.15 \\
\hline Shutdown and reclamation & 0.11 & 0.09 \\
\hline $\begin{array}{l}\text { CO2, SO2 and capture \& storage } \\
\text { of other GHGs }\end{array}$ & 0.08 & 0.07 \\
\hline
\end{tabular}

Similarly, the type II PIFs can be calculated for other criteria. For those criteria whose baseline or threshold has been designed based on regulatory requirements, the PIF value must be 1 or higher. The MDSC will indicate the value of other baselines and thresholds. The PIF formula is designed to grant higher PIF values as performance improves; therefore, the PIF formula must be inverted for those criteria for which the Pactual value decreases to indicate an improvement in the PIF value. For example, criterion SSREO06032's (Deforestation) performance baseline is set at a maximum of $900 \mathrm{ha} / \mathrm{year}$, and the actual performance is 950 ha/year. Using Formula 2, the PIF value is calculated as:

$$
P I F=\frac{900}{950}=0.95
$$

As noted, the performance actual (Pactual) is the denominator while the performance baseline (Pbaseline) is the numerator; consequently, deforestation must decrease in order to improve performance. 


\section{Macrothink \\ Environmental Management and Sustainable Development \\ ISSN 2164-7682 \\ 2014, Vol. 3, No. 1}

Table 3. Areas of excellence's weights project A and B

\begin{tabular}{|c|l|c|c|}
\hline \multicolumn{2}{|c|}{ Areas of Excellence } & \multicolumn{2}{c|}{ Weights } \\
\hline Code & \multicolumn{1}{|c|}{ Name } & Project A & Project B \\
\hline PEME & Project \& environmental management excellence & 0.02 & 0.04 \\
\hline SSRE & Site \& soil resource excellence & 0.08 & 0.10 \\
\hline WRE & Water resource excellence & 0.12 & 0.14 \\
\hline AARE & Atmosphere \& air resource excellence & 0.11 & 0.09 \\
\hline NALE & Natural \& artificial lighting excellence & 0.01 & 0.03 \\
\hline ERE & Energy resource excellence & 0.09 & 0.11 \\
\hline RME & Resources \& materials excellence & 0.13 & 0.08 \\
\hline IDOE & Innovation in design \& operations excellence & 0.08 & 0.11 \\
\hline IBE & Infrastructure \& buildings excellence & 0.05 & 0.03 \\
\hline ERCE & Education, research, \& community excellence & 0.31 & 0.27 \\
\hline
\end{tabular}

Criterion IDOEO06058 (Investment in Innovation) integrates the group of criteria that have type III PIFs. The performance of this group of criteria is measured based on the organization's or project's level of investment. Linking organizations' or projects' performance to economic metrics (e.g., level of investment) demonstrates, to some degree, the level of commitment to sustainable development and performance improvement. The MDSC sets up the different baseline or thresholds for this group of criteria, and they must be indicated as a percentage of an economic metric, such as net income or return on investment. The baseline or threshold for criterion IDOEO06058 is set at $0.5 \%$ of the organization's net income for the immediate previous year at the time of the performance assessment. With a Pactual value of $0.65 \%$, the PIF for criterion IDOEO06058 can be is calculated using Formula 1 as:

$$
P I F=\frac{0.65}{0.50}=1.30
$$

The score (i.e., number of points) for each criterion (i.e., CFS [criteria final score]) is calculated using Formula 3 or 4. Using criterion PEMEP\&D06015 (Development of Environmental Management Systems) as an example, the CFS is calculated as follows:

$$
8.5=10000 \times[0.16 \times 0.02 \times 0.20 \times 1.33]
$$

Where, $10000=$ criterion initial score

$[0.16 \times 0.02 \times 0.20]=$ criterion weight factor

$1.33=$ criterion performance indicator factor

$10000=$ rating system total available points

$0.16=$ sub-division weight

$0.20=$ area of excellence weight

$0.20=$ criterion final weight

$8.5=$ criterion final score 


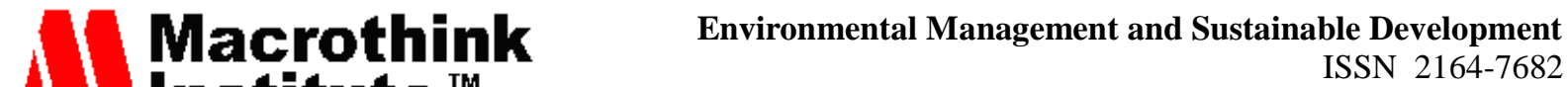 2014, Vol. 3, No. 1}

Table 4. Criteria's weight for project A and B

\begin{tabular}{|c|c|c|c|c|c|}
\hline $\begin{array}{c}\text { Area of } \\
\text { Excellence }\end{array}$ & Criteria Name & Criteria Code & $\begin{array}{l}\text { PIF } \\
\text { Type }\end{array}$ & $\begin{array}{c}\text { Project A } \\
\text { CFW }\end{array}$ & $\begin{array}{c}\text { Project B } \\
\text { CFW }\end{array}$ \\
\hline PEME & $\begin{array}{l}\text { Cumulative Environmental Impact } \\
\text { Assessment }\end{array}$ & PEMEP\&D06003 & I & 0.25 & 0.20 \\
\hline PEME & $\begin{array}{l}\text { Development of Environmental } \\
\text { Management Systems }\end{array}$ & PEMEP\&D06015 & I & 0.20 & 0.15 \\
\hline PEME & $\begin{array}{l}\text { Implementation of Environmental } \\
\text { Management Systems }\end{array}$ & PEMEC06016 & I & 0.30 & 0.35 \\
\hline PEME & Regulatory Compliance & PEMEID\&BC06019 & I & 0.25 & 0.30 \\
\hline SSRE & $\begin{array}{l}\text { Percentage of Re-used excavation } \\
\text { material }\end{array}$ & SSREO06025 & II & 0.35 & 0.20 \\
\hline SSRE & Deforestation & SSREO06032 & II & 0.30 & 0.38 \\
\hline SSRE & $\begin{array}{l}\text { Proportion of non-previously } \\
\text { developed land used }\end{array}$ & SSREO06035 & II & 0.35 & 0.42 \\
\hline WRE & Percentage of recycled water & WREO06037 & II & 0.85 & 0.78 \\
\hline WRE & Acid drainage monitoring & WREO06039 & I & 0.15 & 0.22 \\
\hline AARE & Dust control & AAREO06043 & I & 0.68 & 0.55 \\
\hline AARE & Noise \& vibration monitoring & AAREO06045 & I & 0.32 & 0.45 \\
\hline NALE & $\begin{array}{l}\text { Provision and monitoring of } \\
\text { adequate luminosity }\end{array}$ & NALEO0648 & I & 1 & 1 \\
\hline ERE & $\begin{array}{l}\text { Internal production of energy } \\
\text { consumed }\end{array}$ & EREO06051 & II & 1 & 1 \\
\hline RME & $\begin{array}{l}\text { Improvement in machine } \\
\text { application efficiency }\end{array}$ & RMEO06054 & II & 0.15 & 0.27 \\
\hline RME & Distance of materials suppliers & RMEO06056 & II & 0.85 & 0.73 \\
\hline IDOE & Investment in innovation & IDOEO06058 & III & 1 & 1 \\
\hline IBE & Monitoring of wildlife & IBEO06061 & I & 0.15 & 0.10 \\
\hline IBE & Protection of vegetation & IBEO06063 & III & 0.20 & 0.35 \\
\hline IBE & $\begin{array}{l}\text { Reduction of land area used for } \\
\text { tailing ponds operations }\end{array}$ & IBEO06071 & II & 0.65 & 0.55 \\
\hline ERCE & Community awareness programs & ERCEO06082 & III & 0.10 & 0.15 \\
\hline ERCE & Work satisfaction & ERCEO06087 & II & 0.18 & 0.25 \\
\hline ERCE & Percentage of hours of training & ERCEO06095 & II & 0.25 & 0.38 \\
\hline ERCE & Female-to-male wage ratio & ERCEO06107 & II & 0.47 & 0.22 \\
\hline
\end{tabular}

The sustainability assessment score for the mining process sub-division can be calculated by adding each criterion final score (CFS) or the score for each area of excellence that fall within the sub-division. The sustainability assessment score for Project A is 1632 points, as indicated in Figure 2. Another indicator can be extracted from the score calculation worksheet: the performance index for each area of excellence, which can be calculated by adding each criterion's PIF value within the area of excellence. 


\section{Mll Macrothink}

Environmental Management and Sustainable Development

ISSN 2164-7682

2014, Vol. 3, No. 1

To calculate the sustainability assessment score for Project B, the weights for sub-divisions, areas of excellence, and criteria are replaced as indicated in Tables 1, 2, and 3. Pactual and Pbaselines for each criterion are kept as they are in Project A to be able to compare the impact of the criterion weight factor (CWF) in the final sustainability assessment score between the two projects. Replacing the different weights, the sustainability assessment score for Project B is 2220 points. The weights within each group of assessment are normalized; that is, they sum to one, but the weights have been redistributed. The redistribution of weights within the sub- divisions, areas of excellence, and criteria affect the overall results for both Project A and Project B assessments. This demonstrates not only the critical importance of input by the MDSC in the assessment of weights and establishing the different criteria baselines or thresholds and PIF values, but also the relevance in the relationship between the project's or organization's performance and the weighting process.

\subsection{Potential Minimum and Maximum Performance Scores}

The minimum and maximum potential sustainability assessment scores can be calculated for Projects A and B. Since the performance of a criterion can be linked to PIF type I, II, or III, the minimum and maximum potential scores must be analyzed independently. Using Graph 1, the minimum value of PIF type I for Project A is 1; the relevance category is low-low for all criteria, and the oil production is kept at 65000 barrels per day (BBLD). For other criteria with PIF type II or III, the performance has been reduced by $50 \%$ of the Pbaseline (PIF $=0.5$ ). Since performance is the variable under analysis, the weights for sub-divisions, areas of excellence, and criteria are still the same as in the actual performance assessment scenario previously discussed. The sustainability assessment under the minimum potential score scenario for Project A is 935 points. In comparison with the actual performance (1632 points), the variance is a $57.3 \%$ reduction in points. Under similar assumptions of PIF types I, II, and III, the minimum potential sustainability assessment score for project B is 1254 points, which represents a 56.5\% decrease in comparison with the actual performance score of 2220 points.

The maximum potential sustainability assessment for Projects A and B are calculated under the assumption that the performance has improved $100 \%$ from the previous measurement. For criteria with PIF type I, the relevance factor is described as high-high, while the oil production is still set at65 000 BBLD; therefore, the PIF value is 2, as indicated in Graph 1. For other criteria with PIF type II or III, the increase in performance sets the PIF value at 2. The sustainability assessment under the maximum potential score scenario for Project A is 3200 points. In comparison with the actual performance (1632 points), the variance is a 96.1\% increase in points. Under similar assumptions for PIF types I, II, and III, the maximum potential sustainability assessment score for project B is 4196 points, which represents an increase of $89 \%$ in comparison with the actual performance score of 2220 points. 
Figure 2. Wa-Pa-Su project sustainability rating system score calculation worksheet.

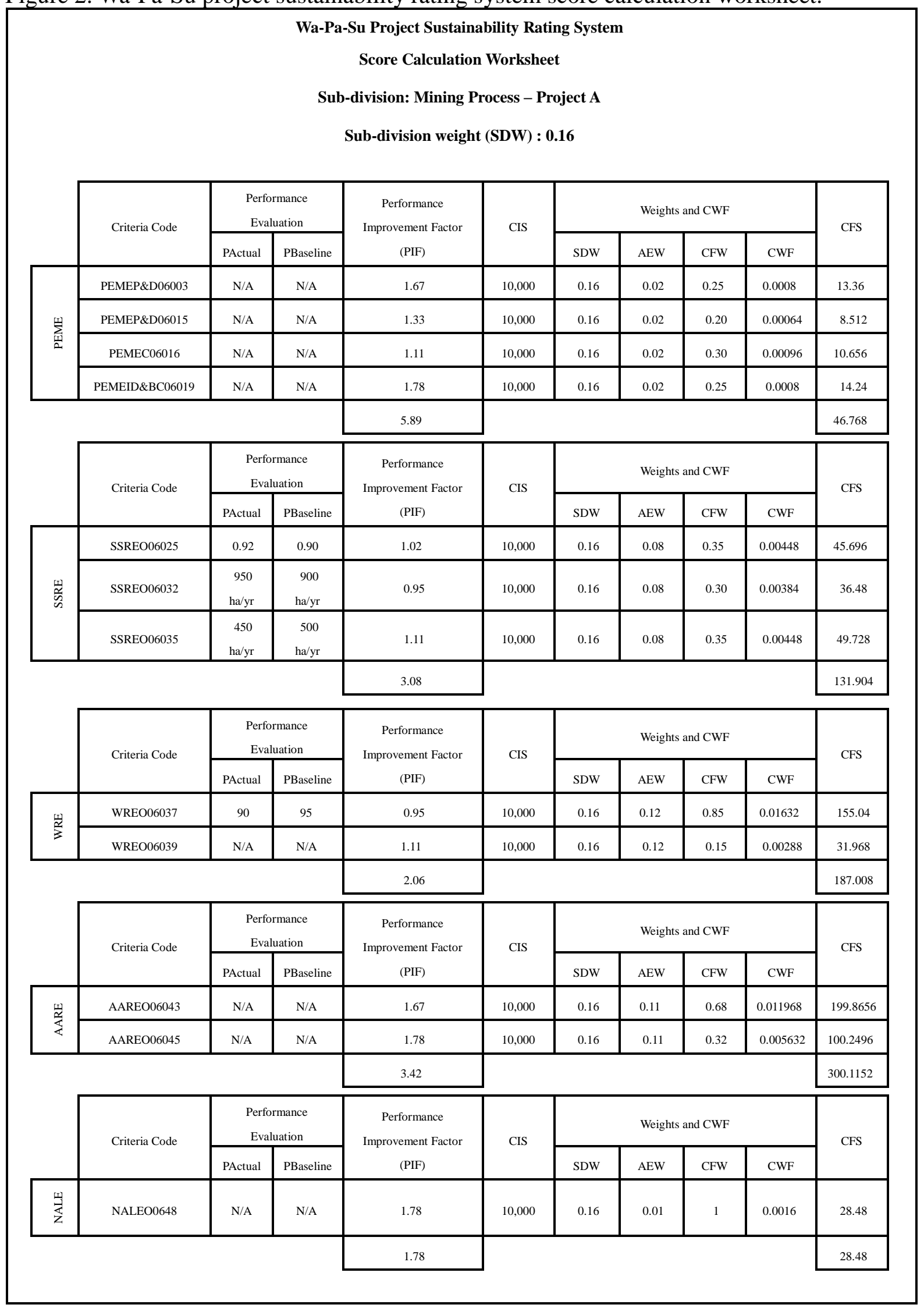


Figure 2. Wa-Pa-Su project sustainability rating system score calculation worksheet (cont'd)

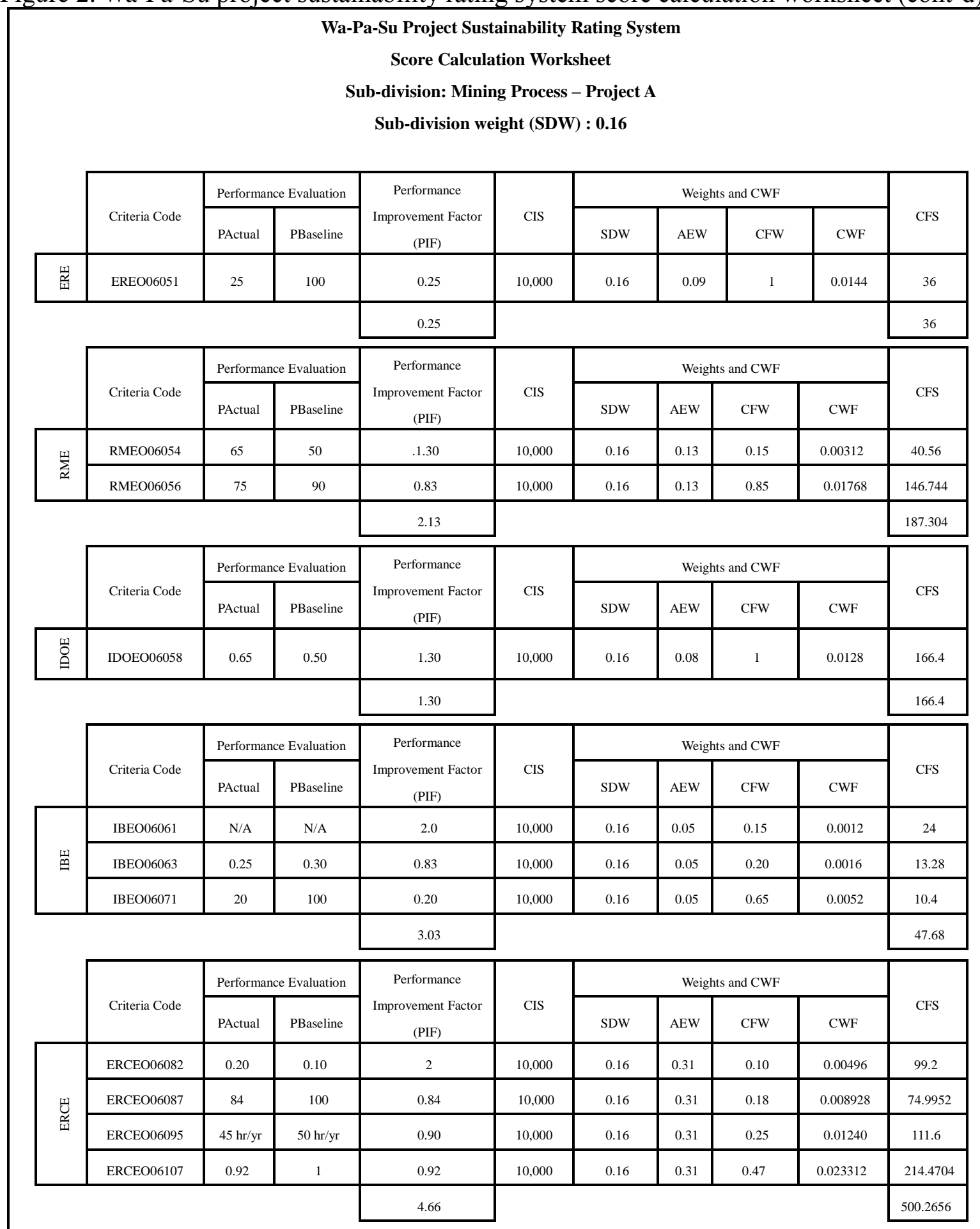

Sustainability Assessment Score: 1631.9248 = 1632 points

\section{Restrictions and Frequency of Measurements}

Currently, oil sands developers and operators report sustainability performance on an annual basis to not only stockholders and internal and external stakeholders, but also to the public in 
general, as their sustainability reports are intended for public access. The application of the Wa-Pa-Su project sustainability ratings system with the current set of data collected for each project becomes a challenge. Although the development and implementation of environmental and sustainability rating system carries a series of benefits already demonstrated in the building industry, other industry contexts require an initial investment for transforming the current planning, construction, and operation practices to consequently impact performance auditing and reporting.

With the aim of avoiding mismanagement of data collection and performance auditing and reporting, sustainability measurement, through the utilization of the Wa-Pa-Su project sustainability rating system, requires setting guidelines in the use of its integrated assessment methodology. Since sustainability is undergoing continuous evolution and projects' and organizations' conditions may change, it is possible to introduce changes to the set of parameters (SDIs) for sustainability assessment; however, there is a series of ramifications when introducing new parameters. New assessment parameters must be set by the rating system design body instead of the company or organization, as performance benchmarking requires uniformity of data collection, auditing, and reporting. The weight of each criterion is expected to change as the result of introducing new parameters of assessment. Once the sub-division, areas of excellence, and criteria weights are set, the MDSC is to serve as auditor of the assessment process. A change in the set of SDIs or weights must be explained and justified by the MDSC on behalf of the change originator, and then approved by the rating system design body, which acts as the governing body. In the event that the assessment methodology proposed in the Wa-Pa-Su project sustainability rating system has not been adopted industry-wide, but instead a project or organization decides to utilize it for internal performance reporting, the MDSC can make changes to the set of SDIs, considering that sub-divisions, areas of excellence, and criteria weights must be re-assessed.

As demonstrated in the simulated case of implementation in which the sustainability assessment scores for Projects A and B were calculated in different scenarios, the weighting process for sub-divisions, areas of excellence, and criteria resulted in the most sensitive factor followed by performance assessment; therefore, the MCDA methodology selected in the weighting process will directly impact the results of the different scores. The MDSC uses the MCDA methodology to determine the weights, including those for the set of criteria in the rating system; therefore, stakeholder identification and selection becomes an additional critical factor in the sustainability assessment process.

Finally, the PIFs for criteria in the rating system can be classified into types I, II, and III (Poveda \& Lipsett, 2013a). PIFs type II and III are calculated through objectives metrics, while PIF type I possesses a certain degree of subjectivity; therefore, the MDSC evaluates the relevance of this group of criteria to then link them to objective measurements. The Wa-Pa-Su project sustainability rating system proposes three objective measurements: energy consumption, GHGs, and BBLD (Poveda \& Lipsett, 2013a). While some organizations or projects collect data for all three parameters, others require the implementation of processes and procedures for such a purpose. Although the PIF type I can be calculated linking the criteria relevance (i.e., relevance category) to each objective measurement, the criteria score 
uses the lowest PIF value with the aim of encouraging performance improvement. While advances in some areas of sustainable development have been made, other areas still require further development in order to implement objectives metrics to assess performance; hence, the design of the PIF type I. As a result, for criteria whose performance is subjective in nature or for which doubts surround the design of metrics, the MDSC input will decide the relevance of the criteria and the final impact (weight) in the overall rating system score.

\section{Discussion}

The different life cycle stages of projects and organizations vary in duration; therefore, sustainability performance measurement must include a degree of dynamism brought by the different factors. Stakeholders, SDIs, and project conditions (e.g., economic, socio-economic, political, scope changes) are among those factors that may vary overtime; these various dynamic factors influence not only the success of sustainability assessment tools, but also the design of the assessment methodology itself. During development and implementation sustainability assessment tools must consider characteristics such as applicability, flexibility, and practicability in order to link the dynamism of the different factors with the goals and vision of sustainability held by a specific group of individuals (e.g., a particular project, organization, or industry).

The integrated sustainability assessment methodology used in the Wa-Pa-Su project sustainability rating system considers a variety of factors found in the three areas of knowledge: sustainable development, multi-criteria decision analysis (MCDA), and continuous performance improvement. The continuous evolution and factors within make every area of knowledge intrinsically dynamic. The integrated assessment methodology takes those dynamic factors into consideration to rate sustainability performance based on improvement over time, while stakeholders accompany the process along the way through weights assessment, SDI selection, and auditing and monitoring the process.

The degree of success in decision-making and sustainability assessment processes measures the effectiveness of stakeholder management. While sustainability assessment tools continue in the search for the most accurate system to measure the advance toward sustainable development, inquiries surround the basis of the different assessment methodologies, stakeholder theory addresses stakeholder definition, identification, and classification; sustainable development attempts to identify what should be measured (i.e., SDIs) and how it should be measured (i.e., metrics), while still trying to find the proper answer regarding what constitutes sustainable development or what makes a project, organization, city, etc. sustainable; and (3) MCDA uses subjective input in mathematical models to bring a degree of rationale and present objective outcome(s).

\section{References}

Alberta Energy. (2013). Fact and Statistics. Retrieve October 25, 2013, fromhttp://www.energy.alberta.ca/OilSands/791.asp.

Berardi, U. (2012). Sustainability assessment in the construction sector: rating systems and rated buildings. Sustainable Development, 20(6), 411-24. http://dx.doi.org/10.1002/sd.532. 


\section{Macrothink}

Environmental Management and Sustainable Development

ISSN 2164-7682

Bloom, E., \& Wheelock, C. (2010). Green Building Certification Programs. Pike Research Report 2Q.

Braganca, L., Mateus, R., \& Koukkari, H. (2010). Building sustainability assessment. Sustainability, 2, 2010-2023. http://dx.doi.org/10.3390/su2072010.

BRE. (2008). A Discussion Document Comparing International Environmental Assessment Methods for Buildings. Glasgow: BRE.

Canadian Natural. (2013). 2011 Stewardship report to Stakeholders. Retrieve October 31, 2013, from http://www.cnrl.com/upload/media_element/589/03/2011-report-to-stakeholders---final-webcopy.pdf.

CAPP. (2013). Environment. Retrieve November 1, 2013, from http://www.capp.ca/canadaIndustry/oilSands/environment/Pages/default.as.

Cenovus. (2013). Corporate responsibility. Retrieve November 3, 2013, fromhttp://www.cenovus.com/reports/corporate-responsibility/

Cole, R. J. (1999). Building environmental assessment methods: clarifying intentions. Building Research and Information, 27 (4/5), 230-246. http://dx.doi.org/10.1080/096132199369354.

Conoco Phillips. (2013). Metrics Oil Sands. Retrieve November 3, 2013 from http://www.cpcsustainability.com/where-we-work/oilsands/metrics-1.cfm

Crawley, D., \& Aho, I. (1999). Building environmental assessment methods: applications and development trends. Building research and information, 27(4/5), 300-308. http://dx.doi.org/10.1080/096132199369417.

Ding, G.K.C. (2008). Sustainable construction-The role of environmental assessment tools. Journal of Environmental Management, 86(3), 451-464. http://dx.doi.org/10.1016/j.jenvman.2006.12.025.

Gibberd, J. (2005). Assessing sustainable buildings in developing countries - the sustainable building assessment tool (SBAT) and the sustainable building lifecycle (SBL). Proceedings of World Sustainable Building Conference, Tokyo.1605-1612.

Haapio, A., \& Viitaniemi, P. (2008).A critical review of building environmental assessment tools. Environmental Impact Assessment Review, 28(7), 469-482. http://dx.doi.org/10.1016/j.eiar.2008.01.002.

Hastings, R., \& Wall, M. (2007). Sustainable Solar Housing, Vol. 1 - Strategies and Solutions. London, UK: Earthscan.

Holmes, J., \& Hudson, G. (2000). An evaluation of the objectives of the BREEAM scheme for offices: a local case study. In: Proceedings of Cutting Edge 2000, RICS Research Foundation, RICS, London. 


\section{Al Macrothink}

Environmental Management and Sustainable Development

ISSN 2164-7682 2014, Vol. 3, No. 1

Mateus, R., \& Braganca, L. (2011). Sustainability assessment and rating of buildings: developing the methodology SBToolPTeH. Building and Environment, 46(10), 1962-1971. http://dx.doi.org/10.1016/j.buildenv.2011.04.023.

Ness, B., Urbel-Piirsalu, E., Anderberg, S., \& Olsson, L. (2007). Categorising tools for sustainability assessment. Ecological Economics, 60(3), 498-508. http://dx.doi.org/10.1016/j.ecolecon.2006.07.023.

Poveda, C. (2013). Introducing the Wa-Pa-Su project sustainability rating system. Oilsands Review, 8(3), 38-42.

Poveda, C., \& Lipsett, M. (2011a). A rating system for sustainability of industrial projects with application in oil sands and heavy oil projects: origins and fundamentals. Journal of Sustainable Development, 4(3), 59-71. http://dx.doi.org/10.5539/jsd.v4n3p59.

Poveda, C., \& Lipsett, M. (2011b). A rating system for sustainability of industrial projects with application in oil sands and heavy oil projects: areas of excellence, sub-divisions, and management interaction. Journal of Sustainable Development, 4(4), 3-13. http://dx.doi.org/10.5539/jsd.v4n4p3.

Poveda, C., \& Lipsett, M. (2013a). Design of performance improvement factors (PIFs) for sustainable development indicators (SDIs) metrics for oil sands projects with application to surface mining operations based on continual performance improvement (CPI). Journal of Sustainable Development, 6(8), 52-70. http://dx.doi.org/10.5539/jsd.v6n8p52.

Poveda, C., \& Lipsett, M. (2013b). The Canadian oil sands: environmental, economic, social, health, and other impacts. Proc. of the 6th Int. Conf. On Sustainable Development and Planning, eds. C.A. Brebbia, WIT Press: Southampton, UK, 575-587. http://dx.doi.org/10.2495/SDP130481.

Shell Canada. (2012). Oil Sands 2012 Performance Report. Retrieve November 5, 2013, from http://www.shell.ca/en/aboutshell/our-business-tpkg/upstream/oil-sands/performance-report.h tml.

Singh, R. K., Murty, H.R., Gupta, S. K., \& Dikshit, A. K. (2012). An overview of sustainability assessment methodologies. Ecological Indicators, 15(1), 281-299.

Suncor. 2013. Report on Sustinability 2013. Retrieve November 5, 2013 fromhttp://sustainability.suncor.com/2013/en/performance/performance-data.aspx.

Syncrude 2013.2010/2011 Sustianability Report. Retrieve November 5, 2013 fromhttp://syncrudesustainability.com/2011/.

\section{Copyright Disclaimer}

Copyright reserved by the author(s).

This article is an open-access article distributed under the terms and conditions of the Creative Commons Attribution license (http://creativecommons.org/licenses/by/3.0/). 